UDC: 338.48.(379.8)

JEL Classification L83; L86; M21; M39

\author{
Alla Levitskaia \\ Doctor of Economics (Habil.), Professor, Faculty of Economics \\ Director, II "InnoCenter" \\ Nadejda Ianioglo \\ Ph.D in Economics, Associate professor, Faculty of Economics \\ Svetlana Curaxina \\ Ph.D in Economics, Associate professor, Faculty of Economics \\ Comrat State University \\ (Comrat, Moldova)
}

\title{
DIGITAL MARKETING STRATEGY APPROACH IN WINE TOURISM: TRADITION VERSUS INNOVATION
}

The tools and technologies of traditional marketing cannot ensure the effective functioning of companies in the field of tourism and services. In this regard, the use of digital marketing technologies becomes a prerequisite for successful tourism activity. The results of the study confirm that the use of the digital marketing strategy approach in Moldovan wineries is at an initial stage while global trends prove the effectiveness of their application in the development of competitive advantages of wine tourism. In this article the authors consider it important and relevant to develop potential in the Republic of Moldova through the implementation of a digital marketing strategy in wine tourism promotion activity.

Key words: wine tourism, digital strategy, mobile marketing.

\section{DOI: 10.15276/mdt.4.3.2020.1}

Statement of the problem in general form and it's connection with important scientific or practical tasks. Currently, the tools and technologies of the traditional marketing apparatus cannot ensure the effective functioning of companies in various sectors of the economy, especially those representing the sphere of tourism and services. In this regard, the use of digital marketing technologies, along with traditional marketing approaches, and in some cases, a complete transition to the use of Internet marketing technologies become a necessary condition for successful development, promotion, increasing competitiveness, reducing costs and increasing the financial performance of tourism businesses [6].

Taking into account the fact that the Republic of Moldova's Wine tourism (WT) is at the initial stage of its development, the authors believe that it is the digital marketing tools that will play a crucial role in promoting the services of this tourism industry in the development of competitive advantages.

Analysis of the latest research and publications, which initiated the solution of this problem and on which the author relies. Wine tourism (WT) considered as a subcategory of Food tourism (OECD, 2012) and as an integral part of a comprehensive travel package including activities based on introduction of regional culture. Also, the wine tourism can be seen as a category by itself (Charters, Ali-Knight, 2001; Getz, 2000) due to its capability of generating economic benefits to an array to local stakeholders (Carlsen, Charters, 2006) [1]. 
Perspectives of management and marketing towards the implementation of Digital through Wifi and IoT in Wine Tourism business described by Pelet J., Barton M., Chapuis C. (2018) [12]. The study information base consists of materials of the World Tourism Organization, National Bureau of Statistics of RM, tourism agencies, legal and regulatory framework of tourism industry. In the process of developing a Strategic plan for the development of vine tourism (WT) have been applied: individual interviews and questionnaires; focus group method; methods of economic analysis. Individual interviews and survey were conducted with managers of small and medium-sized wineries.

Highlighting the previously unresolved parts of the general problem to which the article is devoted. An analysis of recent studies showed an insufficient study of marketing tools used in the tourism industry in Moldova in general and in wine tourism in particular. In addition, digital methods of promoting services in the tourism market of the country are poorly studied and presented. In view of this, this article is aimed at studying the problem of adapting digital marketing strategies in promoting the WT services of Moldova.

Formulation of the purpose of the article (statement of the problem). The purpose of this article is to investigate the development potential of WT in the Republic of Moldova as part of a digital marketing strategy. To achieve this goal, the authors identified the following tasks: identify the specific features of WT and marketing tools; introduce digital marketing tools that can be successfully implemented; describe the effect of digital marketing strategy tools as opposed to traditional.

Statement of the main material of the research with full justification of the scientific results obtained. The Republic of Moldova has the highest planted vineyards density in the world and ranked 19 th among the countries that produce wine. The area of vineyards for wine grapes is 78,000 hectares (3rd place in the Black Sea basin). In total, there are 52,000 winemakers (farmers), 980 enterprises operating in the wine making sector, including nurseries, wineries, agricultural enterprises and cooperatives, engineering companies, packaging and service enterprises, 6 educational institutions, technology transfer, and research centers.

This industry generates about 150,000 jobs, i.e. every 4 th able-bodied citizen is directly or indirectly involved in winemaking. For the last 15 years, about 600 million US dollars have been invested in the development of 30 thousand hectares of vineyards. 24 wineries and 5 specialized agencies in wine tourism are actively involved in viniculture tourism. Compared to 2016, there was an increase in the number of tourists visiting wineries by 31 per cent (175 thousand people), of which local residents are 64 per cent, foreigners - 36 per cent, whose stay in the country is 3.2 people/day and the amount of expenses is of $28.5 \mathrm{EUR} / \mathrm{day}$. Thus, VWT generates about 7 million euros per year [14]. The industry forms 3 per cent of Moldova's GDP and makes up about 12 per cent of exports.

In this case WT is a motivational form of tourism, in order to visit vineyards and winery areas to combine the pleasure of tasting wine products with the opportunity to familiarize themselves with local customs, rural lifestyles and cultural events [8]. The "Wine Route of the Republic of Moldova" program, approved in 2004, marked the beginning of the promotion of the country's image on the basis of grape-wine tourism. This type of tourism is recognized as "anchor" for the development of inbound and domestic tourism. This was facilitated by a comprehensive program to promote Moldova as a wine-tourism destination, an online campaign, participating in specialized fairs and exhibitions, organizing thematic events and study visits, etc. [7].

Moldova's participation in the EU project to promote wine tourism in the black sea basin countries "Black sea wine tourism network" gave a serious impetus to the development of winemaking. The greatest influx of foreign tourists in the framework of WT in fall, when is the wine Festival and in late winter, when the exhibition "Expo Vin Moldova". The study shown

A. Levitskaia, N. Ianioglo, S. Curaxina. Marketing Strategy in Wine Tourism: Tradition 7 Versus Innovation 
that there is a reserve for organizing events that can be visited by domestic tourists and visitors from neighboring countries [8].

A study conducted by Magenta consulting for the National Association of Inbound and Domestic tourism in Moldova showed that more than $40 \%$ of all tourists are interested in Moldovan wine and wineries. So, in $2016,47 \%$ of tourists visited wineries and complexes, in 2018 , the number of such tourists was $60 \%$ of the total number. According to tourists, the most popular event in Moldova is the celebration of the National Wine Day. So, in 2016, 78\% of respondents were satisfied with this holiday, and in 2018 - almost $90 \%$. In addition, $37 \%$ of foreign tourists associated the phrase "Tourism in Moldova" with wine in 2016, and 40\% in 2018.

Promotion of wine tourism in Moldova currently takes place in traditional ways: advertising in the media, participation in thematic international exhibitions, personal sales, etc. However, the low level of information technology using by the wine sector for the promotion of tourism services is indirectly confirmed that in general, the expenses of the manufacturing sector makes average 4,5\%-5\% of all expenses for information technologies in total of country. The expenses for information technologies of accommodation and food service sector makes up less than $1 \%$ of all expenses for information technologies in total of country (table 1).

Table 1 - Expenditures for information technologies in total of country, in manufacturing sector, in accommodation and food service activities sector

\begin{tabular}{lccccc}
\hline & 2014 & 2015 & 2016 & 2017 & 2018 \\
\hline Total, thousand lei & 1305455,1 & 1438895,2 & 1549706,6 & 1743226,5 & 1784061,3 \\
Manufacturing, thousand lei & 49080,5 & 58450,6 & 70323,2 & 71245,1 & 105586,1 \\
Accommodation and food service & 6066,4 & 3655,4 & 6855,8 & 5638,6 & 5780,3 \\
activities thousand lei & 3,8 & 4,1 & 4,5 & 4,1 & 5,9 \\
Manufacturing, \% in total & 0,5 & 0,3 & 0,4 & 0,3 & 0,3 \\
Accommodation and food service & & &
\end{tabular}

Source: National statistics database of Moldova. http://statbank.statistica.md

In recent years, the Internet has developed from a mere source of information into a force that communication experts now call the 'Social Web' (Schindler and Liller, 2012). Related to COVID-19 there have been some major recent developments in the field of social media: Facebook, Twitter and other services allow people to remain participants virtual discovery tours. Wine producers needs to benefit from social media usage in a special way.

Accordantly to study only 17 wineries (from 61st) actively participate in promoting of tourism activity through social networks, mainly in Facebook. The weak use of digital marketing tools to promote tourism services is also confirmed by the extremely low number of own websites of enterprises in the industrial sector and the accommodation and food sector (table 2). These low rates directly affect the low level of promotion of products and services of tourism industry enterprises, including wineries.

Table 2 shows that the number of web-pages of enterprises in the manufacturing sector and the accommodation and food sector is growing. However, the average number of enterprises in the manufacturing sector for the entire period of analysis is more than 3,500 units, of which on average only 331 enterprises $(9 \%)$ have their own web-pages. The average number of accommodation and catering businesses is more than 1,400 units, of which an average of 58 enterprises (4\%) have their own web-pages. 
Table 2 - Number of enterprises which have web pages in manufacturing sector, in accommodation and food service activities sector

\begin{tabular}{lccccc}
\hline & 2014 & 2015 & 2016 & 2017 & 2018 \\
\hline $\begin{array}{l}\text { Quantity of manufacturing } \\
\text { enterprises, units }\end{array}$ & 3474 & 3480 & 3368 & 3643 & 3757 \\
$\begin{array}{l}\text { Share of manufacturing enterprises } \\
\text { sector SMEs which have own web- } \\
\text { page, \% }\end{array}$ & 8,4 & 9,3 & 9,6 & 9,1 & 10,0 \\
$\begin{array}{l}\text { Quantity of accommodation and } \\
\text { food service activities enterprises, } \\
\text { units }\end{array}$ & 1378 & 1431 & 1418 & 1359 & 1613 \\
$\begin{array}{l}\text { Share of accommodation and food } \\
\text { services sector SMEs which have } \\
\text { own web-page, } \%\end{array}$ & 3,2 & 3,1 & 3,7 & 5,4 & 4,9 \\
\hline
\end{tabular}

Source: National statistics database of Moldova. http://statbank.statistica.md

However, according to the authors, the unique "viticulture-IT" tandem can become a driving force for the development of grape and wine tourism and the economy of the Republic of Moldova as a whole. Moreover, the information technology sector set a record in 2019: revenues from the export of this type of service exceeded those from the export of wine. Survey for the WT movement, confirmed the preponderant role of using of social media by wine tourists is six times higher than average and two thirds of winery tours are planned online: CENSIS has reported that in $89 \%$ of the cases wine lovers can be intercepted online. [2]. The world has seen an increase in the use of mobile applications to promote online commerce (figure $1,2)$

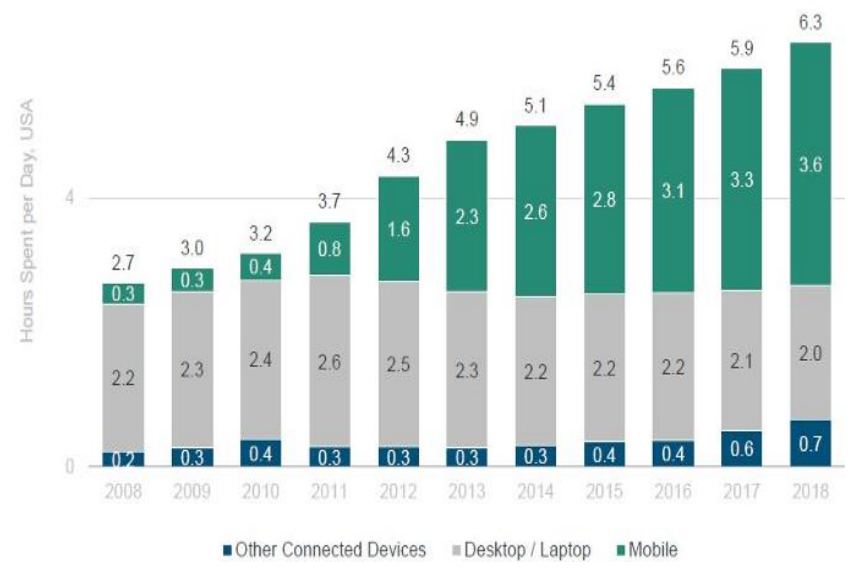

Figure 1 - Daily hours spent with Digital Marketing per adult user, USA Source: BOND Internet trend platform 2019

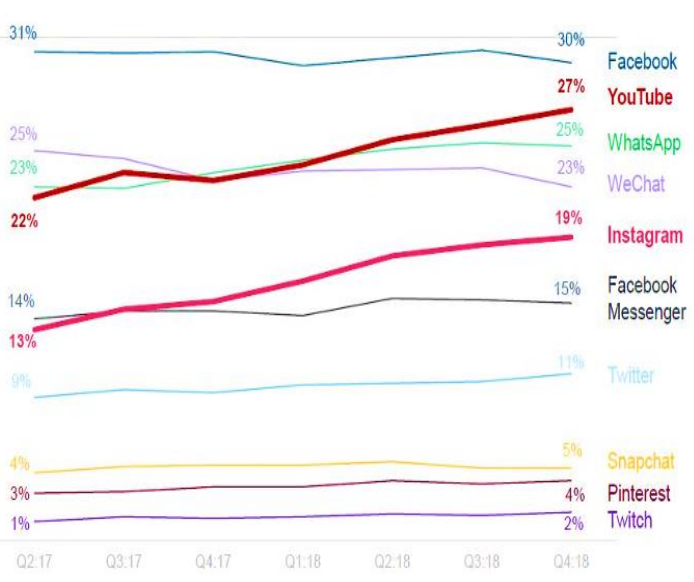

Figure $2-\%$ Internet Users using select platform

Most users of age groups from 20 to 50 years searching for wine tours use such platforms as: Facebook, YouTube, Twitter, Instagram, Pinterest, LinkedIn, Hello Vino and other platforms (table 3). Due to the COVID-19 pandemic, through the use of social media data, online sales have increased, the number of online tastings, training programs. 
Table 3 - Social media regularly used for wine discourse by age, $\%$

\begin{tabular}{lllllll}
\hline Social media & $20 \mathrm{~s}$ & $30 \mathrm{~s}$ & $40 \mathrm{~s}$ & $50 \mathrm{~s}$ & 60 & $70+$ \\
\hline Facebook & 81 & 75 & 58 & 27 & 20 & 6 \\
YouTube & 56 & 61 & 40 & 10 & 8 & 4 \\
Twitter & 53 & 61 & 37 & 13 & 5 & 1 \\
Instagram & 50 & 66 & 36 & 9 & 2 & 1 \\
Pinterest & 31 & 31 & 18 & 12 & 5 & 3 \\
LinkedIn & 17 & 24 & 17 & 5 & 3 & 2 \\
Hello Vino & 21 & 25 & 10 & 1 & 0 & 0 \\
Vivino & 13 & 22 & 6 & 2 & 2 & 1 \\
Delectable & 13 & 14 & 7 & 1 & 0 & 0 \\
\hline $\begin{array}{l}\text { None of the } \\
\text { above }\end{array}$ & 11 & 8 & 29 & 64 & 74 & 90 \\
\hline
\end{tabular}

Source: BOND Internet trend platform 2019.

The practice of widespread use of digital marketing by foreign companies convincingly proves that today effective business development in the field of tourism and services with a focus on medium-and long-term sustainable presence in both the domestic and foreign markets is impossible without the development, systematization and integration of digital marketing strategies into the business. Digital marketing is the practice of using all aspects of traditional marketing on the Internet, affecting the main elements of the marketing mix: price, product, place of sale and promotion.

The conversion of traditional marketing methods to the digital field provides a more effective use of market strategies for market segmentation, targeting of client data groups, differentiation and positioning of goods and services. The Internet environment allows you to create an interface for exchanging ideas, products and services, which strengthens the company's competitive advantages, contributes to improving the efficiency of its work, and at the same time provides the maximum degree of customer satisfaction. Digital technologies of Internet marketing provide a significant increase in the effectiveness of traditional marketing tools due to their adaptation to digital form.

In essence, Internet marketing for WT can be defined as the process of building, maintaining and developing relationships with consumers of tourism services through the creation and implementation of online activities and strategies aimed at meeting the needs of consumers. An obvious disadvantage of traditional marketing is the practical lack of interactive interaction with a potential consumer of the service, while in the case of digital marketing, the consumer often initiates contact and analyzes the information posted.

Digital marketing promotes two-way communication, which, if properly organized, can not only help a travel company sell tourist services to the customer, but also allows you to collect, accumulate and analyze all information about each specific customer (for example, age, gender, income level, previous purchases, suggestions for improving the services offered, etc.). This, in turn, can be used in building revenue management systems in tandem with digital marketing.

The Internet, new digital marketing tools and social media take a crucial role in profitability of wineries: increase domestic and international sales through e-commerce, promote WT, attract 'millennials' and new consumer who are not now more about wine culture. These new marketing tools are especially relevant in the period of overcoming the crisis provoked by a pandemic of COVID- 19 . 
Therefore, it is now necessary to implement transition from the traditional for the wine industry strategic planning approach to digital innovation marketing strategy, which consists of the following stages [3]:

-Selection the digital tools - it needs to be related with specific of vinery, country, wine road.

-Using Big Data - it's important to analyze data about preferences, spending power of tourists, the number of days spent in the journey, preferences types of wine.

-Digitalization Wine Tourism business - winery owner need to have own card on Google Search with link to website, map and present in social media.

-Attracting regular customers - it's important to be included in databases of Apps and regularly mailings news for main customers.

Conclusions from this research and prospects for further developments in this area. WT in the Republic of Moldova today has a high digitalization potential. building strategies for the development of wine-making enterprises on the basis of digitalization of winemaking tourism, widespread use of the capabilities of the IT industry, will make it possible to comprehensively develop this industry, increase its competitiveness and economic efficiency. This study demonstrates that social media already widely used as a communication tool in the wine business. A high level of acceptance of social media tools could be observed in many countries. Facebook is seen as the most important among the available social media tools. Facebook is still the number one tool used, even in the wine industry, but new and innovative platforms occur day by day. Winery owners should be aware of the effectiveness of this modern communication tool, however at the same time they have to define a communication strategy, in which social media is integrated too.

1. Charters, S., Ali-Knight, J. (2001) Who is the wine tourist? Tourism Management, no. 23, pp. 311319.

2. Colombini D. (2013) Italian wine tourism and the web: A necessary wedding. Wine Economics and Policy, vol. 2, issue 2, pp. 111-113.

3. Natalia Andrade Viana. (2016). Digital wine marketing: Social media marketing for the wine industry. BIO Web of Conferences 7.

4. Oklander M.A. (ed.). (2017) Digital marketing - the 21st century marketing model: monograph. Odessa: Astroprint.

5. Getz, D. (2000) Explore wine tourism: Management, development and destinations. New York, NY: Cognizant Communication Cooperation.

6. Kostin K.B. (2014) Internet Marketing as a Modern Means of Successful Development of Tourism Business Companies. Bulletin of St. Petersburg State University of Economics, no. 3 (87), pp. 35-42.

7. Levitskaia A. (2019) Slovak Foreign Policy Association Published within the EU-funded project Gagauzian Modernization Convention.

8. Levitskaia A., Ianioglo N. (2018) Digital marketing technologies as an effective tool for promotion of tourism in the Republic of Moldova. Marketing and digital technologies, vol. 2, no. 3.

9. Levitskaia A., Chaikovska M. (2020) Modern Approaches to Managing Mobile Marketing IT projects. Marketing and Digital Technologies, vol. 4, no. 1, pp. 88-97.

10. Levitskaia A. (2019) Development of the potential of viticulture and wine tourism in ATU Gagauzia. Economic Bulletin of the University, issue 41.

11. OECD. (2012) FOOD AND Tourism Experience. The OECD Korea workshop, OECD studies on Tourism.

12. Pelet J., Barton M., Chapuis C. (2018) Towards the Implementation of Digital through Wifi and IoT in Wine Tourism: Perspectives from Professionals of Wine and Tourism. Management and Marketing of Wine Tourism Business, pp. 207-236. 
13. Szolnoki, G., Taits, D., Nagel, M. and Fortunato, A. (2014) Using Social Media in the Wine Business - An Exploratory Study from Germany. International Journal of Wine Business Research, no.26 (2), pp. 3-19.

14. Vinovations. Available at: https://vinovations.us/moldova (accessed 10 January 2020).

15. Banca de date statistice Moldova. Available at: http://statbank.statistica.md (accessed 10 January 2020).

Алла Левицька, , д-р екон. наук, в.о. професора кафедри економіки, економічний факультет, Комратський державний університет (Комрат, Молдова).

Надія Яніогло, РhD, канд. екон. наук, доцент кафедри економіки, економічний факультет, Комратський державний університет (Комрат, Молдова).

Світлана Кураксина, $P h D$, канд. екон. наук, дочент кафедри економіки, економічний факультет Комратський державний університет (Комрат, Молдова).

Цифрова стратегія маркетингу у винному туризмі: традиція проти інновацій.

Інструменти та технології традииійного маркетингу не можуть забезпечити ефективне функиіонування компаній у сфері туризму та послуг. У зв'язку з цим використання цифрових маркетингових технологій стає необхідною умовою успішної туристичної діяльності. Результати дослідження підтверджують, щз використання підходу до иифрової маркетингової стратегії в молдавських виноробних заводах знаходиться на початковому етапі, тоді як глобальні тендениії доводять ефективність їх застосування у розвитку конкурентних переваг винного туризму. У иій статті автори вважають важливим і актуальним розвивати потенціал в Республіці Молдова через впровадження стратегії ичифрового маркетингу в діяльності з просування винного туризму.

Ключові слова: винний туризм, цифрова стратегія, мобільний маркетинг.

Received to the editor June 9, 2020. 